\title{
Irrigation Water Management in Small Scale Irrigation Schemes: the Case of the Ethiopian Rift Valley Lake Basin
}

\author{
Mihret Dananto Ulsido ${ }^{1}$ and Ermias Alemu ${ }^{2}$ \\ ${ }^{1}$ Wuhan University of Technology, School of Civil Engineering and Architecture \\ ${ }^{2}$ Arba Minch University, Department of Water Resources and Irrigation Engineering \\ crossref $\mathrm{http} / / / \mathrm{dx}$. doi.org/10.5755/j01.erem.67.1.6240
}

(Received in January, 2014; accepted in March, 2014)

\begin{abstract}
Appraisals of irrigation water management scenarios are crucial in project performance monitoring. A comprehensive irrigation water management study has been conducted on four small scale irrigation schemes in the Ethiopian rift valley lake basin. It is observed that from 147 irrigators $68 \%$ faced irrigation water supply unreliability, $79.1 \%$ encountered unfair distribution of water and $66 \%$ underwent through timeliness problem in water distribution occasionally. All the investigated schemes witnessed a weak $(50 \%$ of all scheme users noted poor) organization of irrigation scheme administration. The Water Users Associations (WUAs) lack clear laws/by-laws and strategies to lead small or major canal operations and maintenances. Without a strong WUA it is impossible to think of filling farmer's skill gap, to have a working maintenance strategy, fair distribution of irrigation water, reliable irrigation water supply and timely delivery of irrigation water.
\end{abstract}

Key words: Irrigation, small scale, water management, WUA.

\section{Introduction}

There are mixed perceptions about the contribution of irrigation in general and small scale irrigation (SSI) interventions in particular for poverty reduction and food security improvement. In Ethiopia, although irrigation has been long practiced at different farm levels, there is no efficient and well-managed irrigation water practice (Dessalegn, 1999). The reason could be little efforts made to investigate the irrigated land management and water use in the country. Even some research results have indicated that sometimes no difference is observed between rainfed and SSI user smallholders in their food security status (Peden et al., 2002). The world major grain exporters such as USA, Canada, France, Australia and Argentina produce grain on very productive rainfed agricultural lands, while major grain importers depend on the irrigation to produce grain (De Fraiture et al., 2009). According to Shah et al. (2002), SSI development should result in substantial improvement in household food security and poverty reduction through low cost of maintenance and better institutional support for its sustainability and national economic benefit. A review of several empirical studies by Hussain and Hanjira (2004) indicated a strong linkage between irrigation development and poverty reduction through improving level and security of productivity, livelihood diversification as well as creating employment and income opportunities. Out of 200 sampled irrigator and non-irrigator households in a particular area of Oromia region, only $45 \%$ of them were food secure and more than $70 \%$ were irrigators (Tesfaye et al., 2008). A study by Brabben et al. (2004) and Angood et al. $(2002,2003)$ concluded that irrigation development resulted in considerable rural livelihood, food security, and nutritional improvement among the beneficiaries in Nepal and Bangladesh. In addition, a study by Gebregziabher et al. (2009) using a survey of beneficiaries of selected SSI schemes in the Tigray region of Ethiopia revealed that household income of irrigation users was higher than that of non irrigators by about $50 \%$.

With all these facts on hand and even water resources development for agriculture as a policy 
priority, poorly planned and managed irrigation schemes undermine the efforts to improve livelihoods and expose the people at risk in Ethiopia. Much of an increase in the irrigated area had come because of the expansion of small-scale irrigation in the country. Yet, the existing irrigation development in Ethiopia, as compared to the resources the country has, is negligible (Mintesinot et al., 2005).

Agriculture is the backbone of the country's economy earning a livelihood for more than $85 \%$ of the total population. The country grows a wide variety of irrigated crops including cereals, pulses, cash crops such as chatt (Catha edulis) and different variety of root crops. The vast irrigation land and abundant surface as well as ground water resources are mostly found in the lowlands of the country, which accounts $56 \%$ of the total agro-ecological zone. Farmers, Governmental Organizations and Non Governmental organizations have developed irrigation in the country. Those irrigation structures developed by farmers are traditional ones, constructed using local knowledge and labor. The numbers of such traditional irrigation schemes were increased the last 40 years as the country experienced severe drought and famine because of the fragile environment and erratic weather conditions. Modern irrigation schemes started to appear in the country along with the establishment of state farms since 1977 to produce plantation crops such as cotton, tobacco and others. All these schemes were medium ones constructed and owned by the government.

To achieve sustainable production from irrigated agriculture it is apparent that the management of important resources in irrigated agriculture, water and land is to be improved. In many parts of the country the genetic yield potential of the crops grown is not yet exploited because water is one of the most limiting inputs (Tom et al., 1999). Crop responses to different inputs including fertilizer application depend on the level of water availability (Pala et al., 1996). Application of fertilizers not only increases plant shoot and root growth (Brown et al., 1987), but also increases evapotranspiration and hence metabolism through a large root system and greater extraction of stored water (Cooper et al., 1987). In addition, a large and earlier canopy cover resulting from the application of fertilizers can reduce soil water evaporation and improves field water utilization (Zhang et al., 1998). Hence, it is clear that irrigation and fertilizers are the most important inputs for high crop production and better water management. Generally, in the country and specific to the Rift Valley Lake Basin, several irrigation projects have failed or have had limited livelihood impacts and have been unsustainable because of different limitations, such as less integration of the socio-economic, existing local community water management practices, institutional, technical and policy weaknesses (IFAD, 2005). As far as irrigation management is concerned, the water needs to be gauged and properly utilized, both excessive and inadequate water applications have negative effects (Mihret, 2013). Gauging the water and matching the plant water requirement and the amount of water applied were observed as an inevitable operation in some finger-counted highly performing irrigation schemes in the country (Mihret, 2013). It is critically realized that the success of irrigation projects depends on the participation of the beneficiaries in all phases (conception, planning, construction and operation) of the project (Douglas, 1999).

The questions "how irrigated agriculture is managed with limited water and land resources" have not been yet satisfactorily answered. Irrigation water management information on farmer fields is not available. Thus, this study has been focusing on evaluating the irrigation scheme water management condition of small scale irrigation schemes in the Ethiopian Rift valley lake basin taking four small scale irrigation schemes as a sample. The specific objectives could be:

- Evaluating the management of different irrigation schemes to learn a lesson from the bettered ones.

- Identification of specific management elements that makes a difference in irrigation scheme managements.

- Identification of scheme management problems and their causes in relation to schemes actual conditions.

According to MoWR (2001), it was planned to expand the irrigated agriculture area by more than 470,000 ha between 2002 and 2016, out of which 48 $\%$ would be SSI schemes. Undertaking the water management assessment of the existing SSI schemes in this regard is vital to make an appropriate decision between implementing new interventions and improving the existing ones to enhance the performance and contribution to advance food security and cash income of smallholders.

\section{Methods}

\subsection{The study area}

Ethiopia has about twelve river basins with a potential to irrigate an estimated area of 3.5 million ha, out of which only 190,000 ha $(4.3 \%)$ is actually under irrigation (Makombe et al., 2007; Tesfaye et al., 2008). The Rift Valley Basin (RVB) is one of the major basins having an area of $52,739 \mathrm{~km}^{2}$, covering parts of the Oromia, Southern Nations and Nationalities people (SNNPR) regions (Figure 1). 


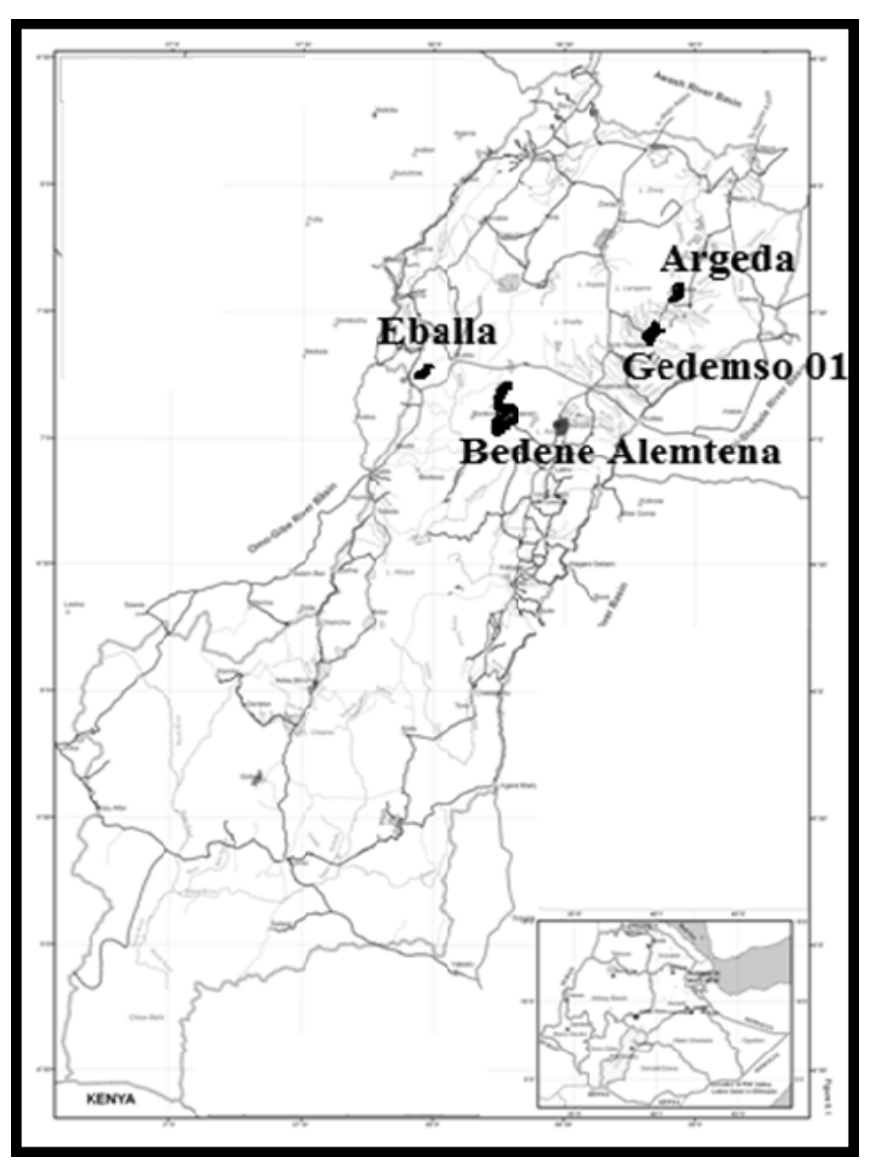

Fig. 1. The study sites

The basin extends between the latitude of $07^{\circ} 00^{\prime}$ and $08^{\circ} 30^{\prime} \mathrm{N}$ and between the longitude of $38^{\circ} 00^{\prime}$ and $39^{\circ} 30^{\prime} \mathrm{E}$. The total mean annual flow from the River Basins is estimated at about 5.6 BMC (Awulachew et al., 2007). It has substantial areas of productive rainfed agricultural land, good rangelands and also irrigation lands due to the great demand for economic and social development. Irrigation development is growing in the basin where about $10 \%$ of the estimated irrigation potential of 139,300 ha of irrigation land is under irrigation, out of which about 4627 ha is provided by small scale irrigation schemes. For this study, four diversion irrigation sites, namely, Gedemso 01, Argeda, Bedene Alemtena and Eballa located within the basin are selected; of which the former two are located in the Oromiya and the latter two are located in the SNNP Administrative Regions. The reasons for the selection of these sites are: accessibility, scale, management type, agro ecological similarity and similarity of market outlet. In all the investigated schemes water is diverted using a weir and conveyed to the field through gravity. Earthen furrows are used to distribute water to each plot on the field.

Gedemso 01 SSI scheme constructed in 2001 by the Oromiya Regional Government is located in West Arsi zone in Arsi Nagelle district, Buku Woldaya Kebele, 30 kilometers to the East of the district capital, Arsi Nagelle and 224 kilometers to the south East of Addis Ababa, Ethiopia. The scheme has a potential to irrigate 180 hectares (BoA 2009/10); out of which 80 hectares are located in Gedemso 01 (BoA
2009/10; Awulachew et al., 2007), and the remains of 100 hectares are located in Gedemso 02.

Argeda SSI scheme constructed by the Oromiya regional government in 2004 is also located in West Arsi Zone in Arsi Nagelle district in Argeda Shaldo Kebele, 39 kilometers to the east of Arsi Nagelle and 233 kilometers to the Southeast of Addis Ababa, Ethiopia. The potential irrigable land of the scheme is 80 hectares (Awulachew et al., 2007).

Bedene Alemtena SSI scheme is located in the SNNP administrative region in Halaba special Woreda. The project is located 12 kilometers from the Woreda capital, Halaba Kulito town. The scheme was constructed by CoSAERSAR to irrigate 200 ha (Awulachew et al., 2007).

Eballa SSI scheme is located in the SNNP administrative region in Kembata Tembaro Zone in Hamido Goforo kebele. It is located at a distance of 120 kilometers to the Northwest of Hawassa, the regional capital. CoSAERSAR constructed the scheme in 1997 to irrigate an area of 120 hectares (Awulachew et al., 2007; Mihret et al., 2013). The planned beneficiaries of the scheme are 627 households. Both schemes use similar diversion structures to guide the water into a gravity water distribution system.

\subsection{Data collection}

The data collection methods include the following: 
- Document Review and Secondary Data Collection

Relevant project documents have been reviewed during the preparation of field data collection tools and development of the report. The reports include performance report, midterm review, baselines, beneficiary assessment, inventory, project completion report and others. Secondary data have been also collected from each sector offices at the Woreda and Kebele level.

- Focus Group Discussion (FGD)

Focus group discussions were held with community representatives with special attention to the water management indicators listed above. In all irrigation schemes, focus group discussions with organized groups were the main sources of information on the water management of SSI projects.

- Field Visit and Observation (transect walk) (FV/TW)

Field investigation and site observation together with Scheme users were the major approach of the study. The field visits were paid plot-by-plot to observe the current water management situations in each scheme. Observations into various schemes helped the research team to know their status and identify constraints in sustaining the services of the schemes to the targeted communities. On the spot discussions with the scheme management committees and scheme users were conducted so as to have first hand information.

Direct observation was exercised starting from the headwork to farm level by selecting a representative section of the scheme. The structured walk through the schemes helped the research team to assess particular indicators (water availability, maintenance status, soil type, soil characteristics, type of crop, homestead, grazing land, type of livestock, watershed status, etc). It provided a good first overview of the irrigation scheme and plot use.

- Household Survey (HH)

Household survey in the four irrigation schemes was conducted using a structured questioner regarding the water management of irrigation schemes in the community. Farm households who were directly using irrigation schemes were surveyed to see water management of the irrigation schemes. Primarily, purposive sampling based on performance and convenience were employed to select the four irrigation schemes; in the second stage, each selected scheme was purposively divided into three strata based on their relative location with respect to the diversion structure as head, middle and tail reach. That stratification helped in classifying schemes into the smaller areas that are homogenous in terms of access to water and irrigation infrastructure. A probability sampling method involving a simple random sampling technique was used to select the respondents. Proportional sampling was employed to pick female-headed $\mathrm{HH}$ and male headed households from each strata. For irrigation water management investigation 147, (two of them were rejected after data collection for justifiable reasons from Argeda 01 and Eballa) (Table 1) irrigation scheme user households were involved.

\subsection{Sampling protocol}

Table 1. Distribution of samples at each irrigation scheme

\begin{tabular}{|c|c|c|c|c|c|c|c|c|}
\hline \multirow{3}{*}{ Name of scheme } & \multirow{2}{*}{\multicolumn{2}{|c|}{ Total }} & \multicolumn{6}{|c|}{ Irrigation scheme } \\
\hline & & & \multicolumn{2}{|c|}{ Head } & \multicolumn{2}{|c|}{ Middle } & \multicolumn{2}{|c|}{ Tail } \\
\hline & $\begin{array}{c}\text { Female } \\
\text { HH }\end{array}$ & $\begin{array}{c}\text { Male } \\
\text { HH }\end{array}$ & $\begin{array}{c}\text { Female } \\
\text { HH }\end{array}$ & $\begin{array}{c}\text { Male } \\
\text { HH }\end{array}$ & $\begin{array}{c}\text { Female } \\
\text { HH }\end{array}$ & $\begin{array}{c}\text { Male } \\
\text { HH }\end{array}$ & $\begin{array}{c}\text { Female } \\
\text { HH }\end{array}$ & $\begin{array}{c}\text { Male } \\
\text { HH }\end{array}$ \\
\hline Argeda 01 & 7 & 28 & 1 & 5 & 4 & 13 & 2 & 10 \\
\hline Gedemso 01 & 8 & 34 & 1 & 5 & 3 & 19 & 4 & 10 \\
\hline Bedene Alemtena & 6 & 21 & 1 & 2 & 3 & 9 & 2 & 10 \\
\hline Eballa & 7 & 34 & 2 & 3 & 3 & 20 & 2 & 11 \\
\hline Total & 28 & 117 & 5 & 15 & 13 & 61 & 10 & 41 \\
\hline
\end{tabular}

\subsection{Indicators}

The indicators presented in Table 2 were used to assess water management in SSI projects. These indicators were selected according to the context of this investigation (focusing on irrigation water management), and the cost of data collection and processing (Biswas, 1984, 1985). 
Table 2. Indicators used for investigation

\begin{tabular}{|c|c||}
\hline Indicators & Method of Data collection \\
\hline Fair distribution of Irrigation water & Household survey to investigate Fair distribution of Irrigation water \\
\hline $\begin{array}{c}\text { Reliability of Irrigation Water } \\
\text { Supply }\end{array}$ & Household survey to investigate Reliability of Irrigation Water Supply (survey) \\
\hline $\begin{array}{c}\text { Timely delivery of Irrigation water } \\
\text { WUA Organization }\end{array}$ & $\begin{array}{c}\text { Household survey to investigate Timely delivery of Irrigation water (Survey) } \\
\text { survey) }\end{array}$ \\
\hline Information and education & Acquired irrigation systems management skills (Survey and FGD). \\
\hline Status of irrigation services & Presence of organized maintenance strategy (Survey, FGD, KII). \\
\hline
\end{tabular}

\section{Results and Discussion}

For the rapidly expanding small scale irrigation farms in the area, there is very little or no information regarding appropriate management of irrigation water and crop management practices in the four investigated irrigation projects. Knowledge about irrigation water management practices is very crucial to improve the productivity of irrigated agriculture through the application of scientific and modern irrigation water management technologies with an ultimate goal of improving livelihood of smallholder farmers in the respective irrigation schemes without any adverse effect on the social and environmental arena. Employing the aforementioned methods, the management parameters like fairness in irrigation water distribution, timely delivery of irrigation water and reliability of irrigation Water Supply in the four schemes were investigated. Each of these findings has been presented in this section.

\subsection{Fair distribution of Irrigation water}

In all irrigation schemes (mean of $79.1 \%$ ), in their field experience users (Figure 1) occasionally faced unfair distribution of irrigation water. In Gedemso 01 irrigation project, for instance, unfair distribution of irrigation water is a serious problem due to illegal water users and a weak Water Users Association. In all other schemes, the unfairness is attributed to the corrupt Water Users Association and stake of headwater users.

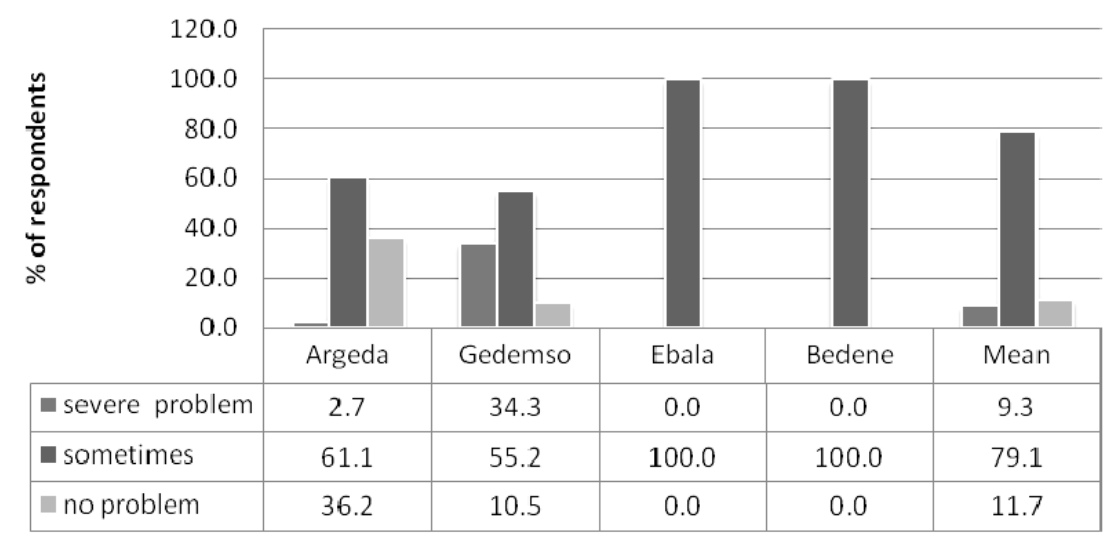

Fig. 2. Irrigation water management - Fair distribution of water

\subsection{Reliability of Irrigation Water Supply}

Unreliability of irrigation water supply due to the poorly functioning irrigation infrastructure and night illegal water users (vandalism) is sometimes observed by $68 \%$ of the irrigation schemes users. Unauthorized water users, seepage, canal blockage for washing clothes, and herds of cattle drinking from the canals may also contributed to water supply unreliability. 


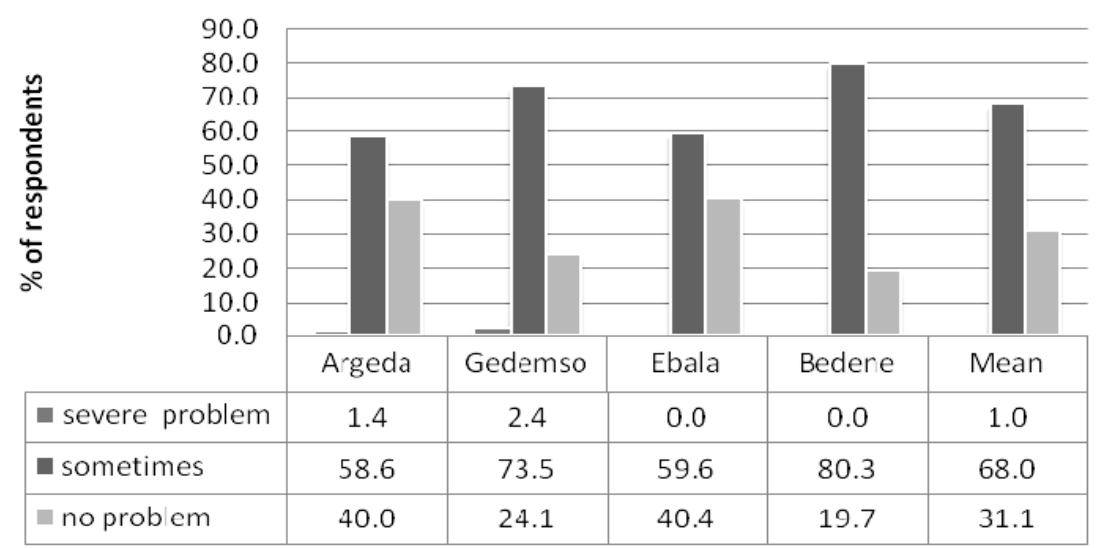

Fig. 3. Irrigation water management - Water supply reliability

\subsection{Timely Delivery of Irrigation Water}

Irrigation is an essential component of agricultural water management where greater production of food and fiber is required under severe constraints of water resources. Humanity is challenged to increase production using the existing resources, mainly land and water, efficiently. Plants are efficient in sensing water stress and respond to it accordingly. Untimely delivery of water has a significant impact on performance of crops. In all irrigation schemes $66 \%$ of irrigation water users in their practical irrigation life have sometimes experienced a problem of timely water delivery according to their schedule. The problem is mainly attributed to poorly functioning irrigation canals, seepage, illegal water users, and canal blockage to use the water for other purposes.

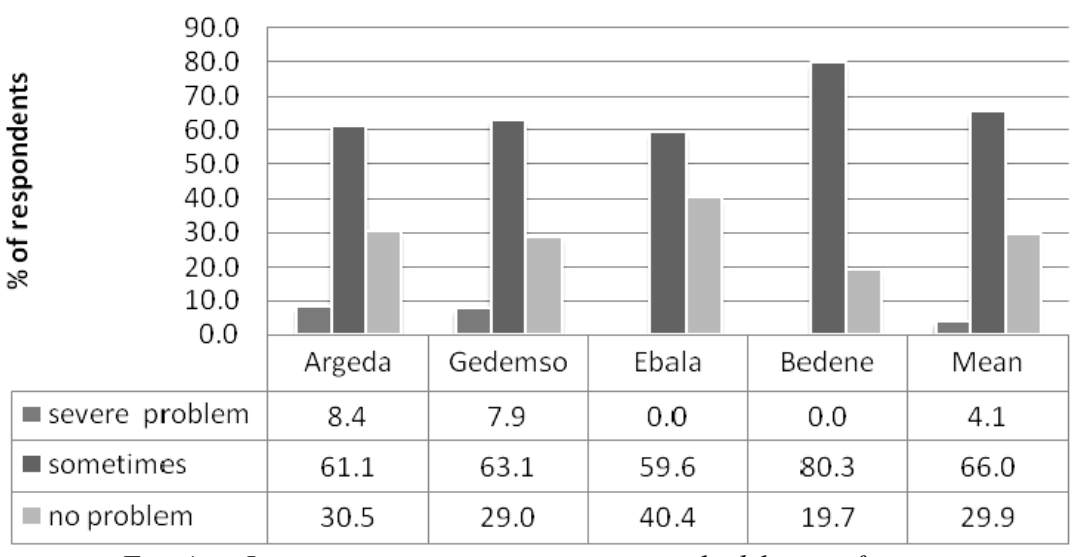

Fig. 4. Irrigation water management-timely delivery of water

\subsection{Participation}

WUA Organization. Effective organizational structure of the Water Users Association in irrigation schemes creates the ability to facilitate working relationships between various entities and to improve the working efficiency within the organizational units. Without the WUA, the efficient irrigation scheme management is impossible. By strengthening the management capacity of WUA, legal and smooth handover of schemes after the construction are critical to sustain performances. In this case study, it is observed that there is a positive correlation between the schemes that have an established WUA and better water management. Even though technical aspects contribute, the most of weak and poor water management in irrigation projects is derived from poor management of the schemes. Organizational strength is critical in hampering the precedence of most water management related problems.

$65.2 \%$ of household farmers in Argeda and $74.7 \%$ in Gedemso 01 irrigation schemes appreciated the organizational structure and performance of their WUA (moderate and well organized respectively). While, $59.6 \%$ of household users in Eballa and $80.3 \%$ of household users in Bedene Alemtena irrigation projects complained about the poor performance and bad organizational structure of their WUA. 


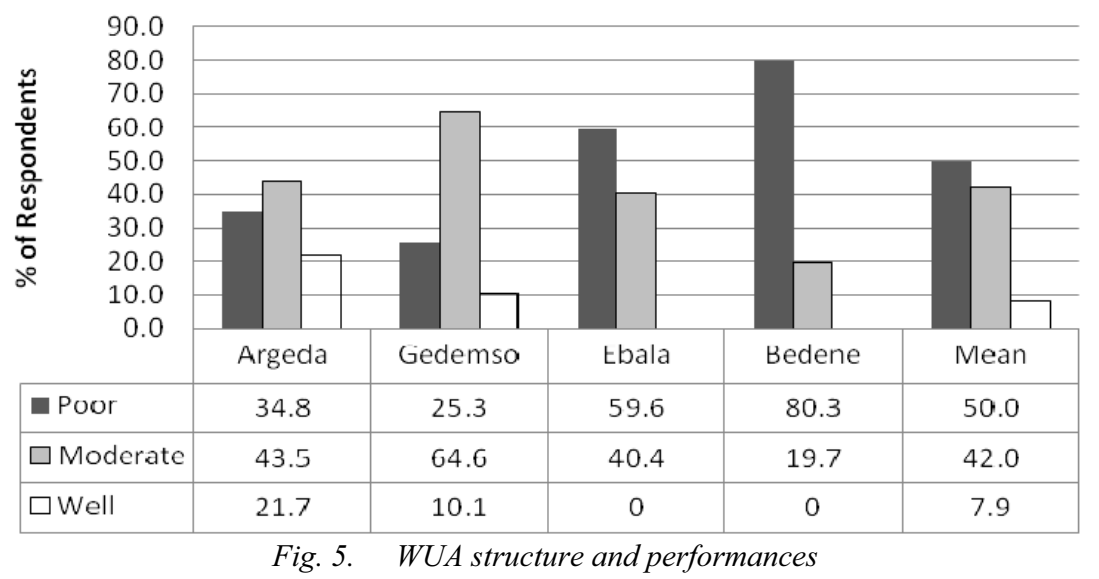

Information, education and communication. Except Gedemso 01, majority of the households in the

irrigation schemes do have sufficient knowledge about irrigation.

\section{Do you have suffcient irrigation knowledge?}

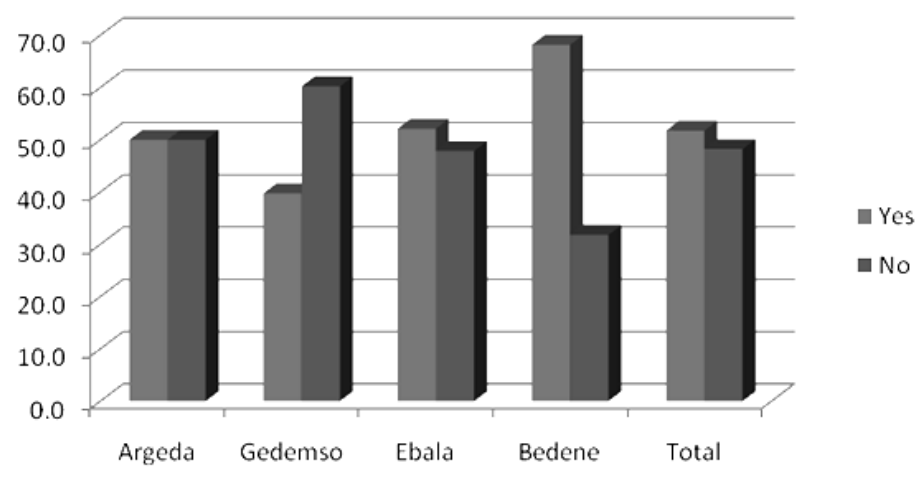

Fig. 6. Irrigation knowledge of users in each scheme

Table 3. Members of WUA who have taken different training in percentage

\begin{tabular}{|l|c|c|c|c||}
\hline \multirow{2}{*}{\multicolumn{1}{c}{ Types of training taken }} & \multicolumn{2}{|c||}{ WUA members who have taken different training (\%) } \\
\cline { 2 - 5 } & $\begin{array}{c}\text { Argeda } \\
\mathbf{0 1}\end{array}$ & $\begin{array}{c}\text { Gedemso } \\
\mathbf{0 1}\end{array}$ & $\begin{array}{c}\text { Bedene } \\
\text { Alemtena }\end{array}$ & Eballa \\
\hline Irrigation scheme administration & 50 & 55.6 & 62.5 & 83.3 \\
\hline Irrigation scheme O\&M & 62.5 & 44.4 & 62.5 & 66.7 \\
\hline Irrigated crop production and management & 62.5 & 44.4 & 87.5 & 66.7 \\
\hline Irrigation scheme administration & 62.5 & 55.6 & 87.5 & 83.3 \\
\hline Average (\%) & 59.4 & 50 & 75 & 75 \\
\hline
\end{tabular}

Nevertheless, during the FGD it is observed that the proportions of WUA members who have taken the training are different.

Lower percentages of participants were recorded for those who took training at Argeda 01 and Gedemso 01 irrigation schemes. Institutional support towards establishing better irrigation management through training would play an inevitable role in enhancing the effect of irrigation schemes on the sustainability of local economic development.

\subsection{Canal Maintenance Strategy}

Canal maintenance is the major task of farmers that takes much of their time and labor. Prolonged desiltation season poses major difficulties on their crop selection options and forces them not to stick to crops that can satisfy their market opportunities. All the schemes investigated lack a clear canal maintenance strategy. $94.5 \%$ of the respondents of all schemes (Figure 7) believe that their canal maintenance strategy is not good (it is either fair or poor). 


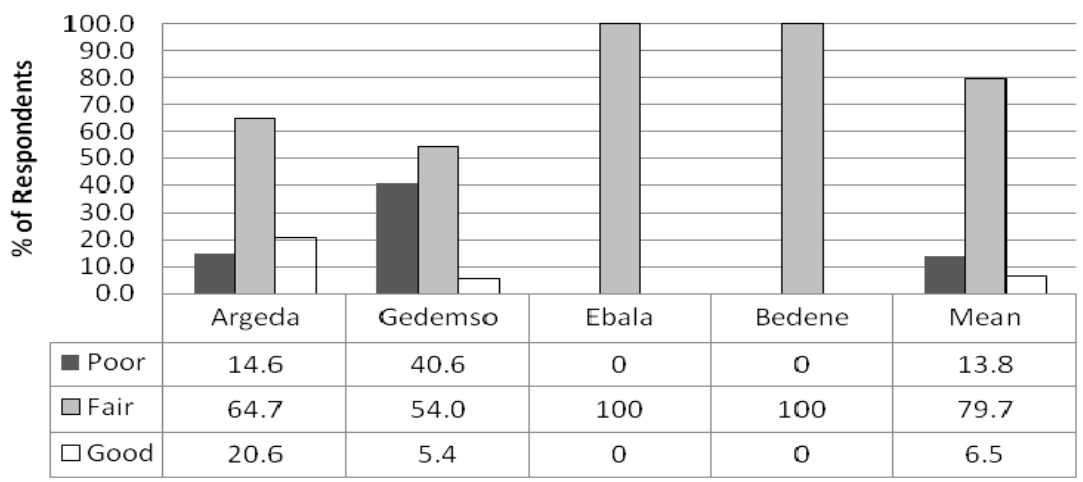

Fig. 7. Presence of clear canal maintenance strategy in each scheme

In all the schemes observed the canal crosssections and gradients were deteriorated. Frequent unwanted canal obstructions and blockage either by foreign materials or due to the growth of vegetative coverings were observed (Figure 8). In all schemes, lack of a proper canal crossing at a logical location forced the cattle to jump over or walk through the canals breaching the canal's profile.

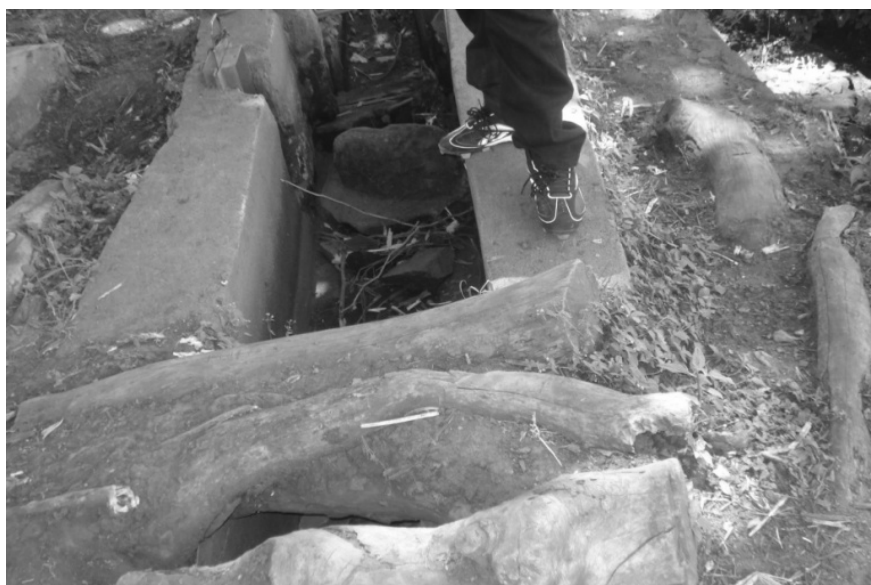

Fig. 8. Canal crossing made from abandoned log, flow obstruction in Argeda SSI

In most farmlands of the basin, the landholding is declining to support decent livelihoods. The old practices of fallow cropping which used to be upheld in the area are being eroded. In irrigation fields it is impossible to think of such practices. The only option is to maintain irrigation infrastructures and sustain the fertility of fields through natural or artificial ways. The recent invasion of eucalyptus (Eucalyptus spp.) along the main canals in irrigated fields has made maintenance activity frequent and costly, which calls for the attention of policy makers to enforce strict regulation in land use. The community in Eballa and Bedene Alemtena irrigation schemes has indicated that most of absentee-land owners who live in the nearby villages/towns plant eucalyptus trees in fertile lands, as they do not need much supervision and labor input. Poor/weak organization of the water committee leads to irrigation schemes to lack a clear maintenance strategy. These could be the reason why the Eballa irrigation scheme was underutilized (Table 4). However, this development is affecting the farming system in general and irrigated field's utilization and productivity in particular. Nonresident farmers actually are not easily accessible and non-cooperative during canal maintenance operations.

Table 4. Irrigated field utilization (percentage) (average of five years, 2009-2013)

\begin{tabular}{||l|c|c|c|c||}
\hline \multicolumn{1}{|c|}{ Name of scheme } & $\begin{array}{c}\text { Scheme } \\
\text { type }\end{array}$ & $\begin{array}{c}\text { Command } \\
\text { area, ha }\end{array}$ & $\begin{array}{c}\text { Irrigated } \\
\text { area, ha }\end{array}$ & Utilization, \% \\
\hline Argeda SSI & Diversion & 80 & 78 & 97.5 \\
\hline Gedemso 01 SSI & Diversion & 80 & 96 & 120.0 \\
\hline Eballa SSI & Diversion & 120 & 85 & 70.8 \\
\hline Bedene Alemtena SSI & Diversion & 200 & 276 & 138.0 \\
\hline
\end{tabular}

To wind up this discussion, it is apparent that at a scheme level, the water management issues need to be conducted by the WUAs, and it is their mandate to operate and maintain the system. Actually, to solve all irrigation scheme water management problems a wellorganized WUA is needed.

This study has also confirmed that efficient water management is found to be a major challenge in irrigation schemes of the basin. Organizational and 
management problems observed at a scheme level include:

- $\quad$ Lack of an efficient WUA.

- Water management problems, such as equitable water use, high water loss due to seepage as a result of a poor maintenance strategy, uncontrolled water use, vandalism and water theft.

- Scheme management issues, such as lack of structural maintenance, lack of proper operation of the structures and lack of the ownership sense are the major constraints in all schemes.

Poor irrigation scheme water management has been an appreciated problem of all four irrigation schemes regardless of the scheme design and operation. Due to non-coordination of scheme management, water management problems have been manifested on designed crop calendar, proposed cropping pattern, and weak production and productivity.

\section{Conclusions}

The need for production and productivity improvement to alleviate the challenge of food insecurity in the country obligates the use of irrigation, particularly in water deficit areas. However, the production gain from irrigated agriculture is below the expected value due to the inefficient scheme water management. Generally, water supply unreliability (68\% of all scheme users' observation), unfair distribution of water $(79.1 \%$ of all scheme users' opinion) and timeliness of water distribution (66\% of all scheme users' remark) are major problems in all investigated schemes. All the schemes witnessed a weak organization (50\% of all scheme users noted poor organization) of irrigation scheme administration. The WUAs lack clear laws/by-laws and strategies to coordinate and conduct minor or major canal maintenances. In all schemes, there are no documented administration matters dealt with users. No scheme auditing has been done throughout the life of the schemes. All actions have been dealt with spontaneously and farmers use their personal judgment in selecting the cropping pattern. As a result, they have been facing the overlap of crop seasons (irrigated crops harvesting season overlaps with rainfed season), market elasticity and post harvest-handling problems. Most of these water management issues shall be sorted out by having an organized WUA. Without a strong WUA it is impossible to think of filling farmer's skill gap, to have a working maintenance strategy, fair distribution of irrigation water, reliable irrigation water supply and timely delivery of irrigation water.

\section{Acknowledgements}

The authors would like to thank UNESCO-IHE (the University Water Sector Partnership- Demand Driven Action Research project) for financing this research, and Arba Minch and Hawassa Universities for providing the necessary facilities like office and vehicles. Our special thanks will be for Oromiya Water Mines and Energy bureau, Southern Nations Nationalities and Peoples Regional States Irrigation Development and Scheme Administration Agency. We are also highly indebted to Dr. Flip Wester, Dr. Frank van Steenbergen, Mrs. Susan Graas, Mr. Yohannis Geleta, Mr. Tadele M, Mr. Roba, Mr. Adunga E., Dr. Mekonen G. and Mr. Gezahegn Wejebo for their all round support to realize this research.

\section{References}

Angood, C., Chancellor, F., Hasnip, N., Morrison, J., Smith, L. (2002). Contribution of irrigation to sustaining rural livelihoods: Nepal case study. HR Wallingford technical report OD/TN 113, Wallingford, UK.

Angood, C., Chancellor, F., Morrison, J., Smith, L. (2003). Contribution of irrigation to sustaining rural livelihoods: Bangladesh case study. HR Wallingford technical report OD/TN 114, Wallingford, UK.

Awulachew S. B., Merrey D. J., Kamara A. B., Van Koppen B., F. Penning de Vries and Boelee E.(2005) Experiences and Opportunities for promoting SmallScale/Micro Irrigation and Rainwater Harvesting for Food Security in Ethiopia. Addis Ababa International Water Management Institute, Working Paper 98.

Awulachew, S. B.; Yilma, A. D.; Loulseged, M.; Loiskandl, W., Ayana, M.; Alamirew, T. (2007). Water Resources and Irrigation Development in Ethiopia. Colombo, Sri Lanka: International Water Management Institute. 78p. (Working Paper 123).

Awulachew,S.B. and Merrey,J.D.(2007). Assessement of Smale Scale Irrigation and water Harvesting in Ethiopian Agricultural Development. International Waeter Management Institute (IWMI), Addis Ababa, Ethiopia.

Biswas, Asit K. (1985). Evaluating irrigation's impact: guide lines for project monitoring, Ceres, Vol 18, No 4,pp 26-32.

Biswas, Asit K. (1984). Monitoring and evaluation of an irrigation system. International Journal of Water Resources Development, Vol 2: No1,pp 3-25. http://dx.doi.org/10.1080/07900628408722304.

Brabben,T.;Angod,C.;Skutsch,J.;Smith,L.,(2004).Irrig ation can sustain rural livelihood: evidence from Bangladesh and Nepal. HR Wallingford Ltd. UK.

Brown S.C., Keatinge J.D.H., Gregory P.J., Cooper P.J.M. (1987): Effects of Fertilizer, Variety and Location on Barley Production under Rainfed Conditions in Northern Syria: I. Root and Shoot Growth. Field Crops Res.; 16:5366. http://dx.doi.org/10.1016/0378-4290(87)90053-0.

De Fraiture,C.; Molden, D.; Wichelns, D.(2009). Investing in water for food, ecosystems, and livelihoods: An overview of the comprehensive assessment of water management in agriculture. International Water Management Institute PMB, CT 112, Cantonments, Accra, Ghana.

Dessalegn Rahmato (1999): Water Resource Development in Ethiopia. Forum for Social Studies, Addis Ababa, Ethiopia.

Dougherty T.C., Hall A.W (1995). Environmental impact assessment of irrigation and drainage projects. FAO. Rome Itally. 
Douglas, L. V., Juan A. S., (1999). Transfer of Irrigation Management Services. Guideline: Irrigation and Drainage Paper. No. 58. FAO, Rome.

Gebregziabher, G.; Namara,E.R.; Holden,S.,(2009). Poverty reduction with irrigation investment: An empirical case study from Tigray, Ethiopia. Agricultural Water development. http://dx.doi.org/10.1016/j.agwat.2009.08.004

Hussain, I., Hanjra, M.A., (2004). Irrigation and poverty alleviation: review of the empirical evidence. Irrigation and Drainage 53, 1-15. http://dx.doi.org/10.1002/ird.114.

IFAD (International Fund For Agricultural Development) (2005). Special country program phase II. Interim evaluation report number 1643-ET, Ethiopia IFAD (International Fund for Agricultural Development).

Makombe, G., Kelemework, D., Aredo, D., (2007). A comparative analysis of rain-fed and irrigated agricultural production in Ethiopia. Irrigation and Drainage Systems 21, 35-44. http://dx.doi.org/10.1007/s10795-007-9018-2

Mihret Dananto Ulsido, (2013). Irrigation System Analysis Techniques with Practical Illustrations. LAP Lambert Academic Publishing AG \& Co. KG Lap Lambert. Saarbrücken, Germany.

MoWR (Ministry of Water Resources) (2001). Irrigation development strategy (Component of the water sector development program). Draft report. Ethiopia, Addis Ababa.

Pala, M., Matar A. \& Mazid A. (1996): Assessment of the Effects of Environment Factors On the Response of Wheat to Fertilizer in On-Farm Trials in Mediterranean Type Environments. Experimental Agriculture, 32(2): 339 349. http://dx.doi.org/10.1017/S0014479700026272.

Peden, D.; Dubale, P.; Tsegaye, E.; Behailu, M.; Tadesse, G.; Gebremedhin,G.,(2002). Community-based irrigation management in Ethiopia: Strategies to enhance human health, livestock and crop production, and natural resource management. International Water Institute Imanagement Institute (IWMI), Addis Ababa, Ethiopia.

Shah, T.; van Koppen, B.; Merrey, D.; de Lange, M. and Samad, M. (2002). Institutional alternatives in African smallholder irrigation: Lessons from international experience with irrigation management transfer. Research Report 60. Colombo: IWMI.

Tesfaye, A.; Bogale, A.;Namara, E.R.;Bacha,D.,(2008). The impact of small-scale irrigation on household food security: The case of Filtino and Godino irrigation schemes in Ethiopia. Irrigation Drainage Syst 22:145-158. http://dx.doi.org/10.1007/s10795-0089047-5.
Tom C., Moges Worku, Messele Endale, Carmela G. A., Frank B., Abebe Wolde Amanuel and Kibru Mamusha, (1999). Programmatic Environmental Assessment of SmallScale Irrigation in Ethiopia: for Catholic Relief Services, U.S. Catholic Conference. Baltimore, Maryland.

Zhang H., Oweis T., Garabet S., Pala M. (1998): Water Use Efficiency and Transpiration Efficiency of Wheat under Rainfed and Irrigation Conditions in a Mediterranean Environment. Plant Soil; 201:295-305. http://dx.doi.org/10.1023/A:1004328004860.

Mihret Dananto Ulsido - PhD candidate, Wuhan University of Technology, School of Civil Engineering and Architecture.

M.Sc in Water Resources Engineering, M.Sc in Resources Engineering, Lecturer, School of Biosystems and Environmental Engineering, Hawassa Institute of Technology, Hawassa University, Ethiopia.

Main research area: systems analysis, water resources engineering and management, contaminant transport, environmental quality, surface and ground water hydrology.

Address: Wuhan University of Technology, School of Civil Engineering and Architecture, 122 Luoshi Road, Hongshan District, Wuhan, Hubei, 430070, P.R.China,

Tel.: $\quad+8613554180085$

E-mail: mihret@gmail.com

Ermias Alemu - PhD candidate in AgroParis University, Montpellier, France. Currently works in Department of Water Resources \& Irrigation Engineering, Institute of Technology Arba Minch University, Ethiopia

Main research areas: Integrated river basin management (water resources development, water resources management and irrigation management), Irrigation System analysis (technical, social, environmental and economical issues), Water resources engineering and management

Address: $\quad$ P.O. Box 21, SNNPR State, Arba

Minch Institute of Technology, Arba Minch,

Ethiopia

Tel.: $\quad+251911479239$

E-mail:_ermialem@gmail.com 


\title{
Drẻkinimo vandens valdymas mažose drèkinimo sistemose: Etiopijos didžiojo Lūžių slẻnio ežero baseino atvejo analizė
}

\author{
Mihret Dananto Ulsido ${ }^{1}$ ir Ermias Alemu ${ }^{2}$ \\ ${ }^{1}$ Wuhan technologijos universitetas, Civilinès inžinerijos ir Architektūros mokykla \\ ${ }^{2}$ Arba Minch universitetas, Vandens ištekliu ir drékinimo katedra
}

(gauta 2014 m. sausio mèn.; atiduota spaudai 2014 m. kovo mén.)

Drèkinimo vandens valdymo scenarijų analizė yra labai svarbi atliekant projektinès veiklos stebėseną. Buvo atliktas išsamus Etiopijos Lūžių slènio ežero baseino keturių mažos apimties drèkinimo sistemų vandens valdymo tyrimas. Buvo pastebėta, jog iš 147 drékinimų atvejų 68 proc. susiduriama su drèkinimo vandens tiekimo nepatikimumu, 79,1 proc. - su neobjektyviu vandens paskirstymu ir 66 proc. - su laiku netiekiamu vandeniu. Visos tirtos valdymo schemos rodo, kad silpnas (50 proc. visų schemų vartotojų ìvertintos silpnai) organizacinis drèkinimo sistemos administravimas. Vandens vartotojų asociacijos (VVA) neturi aiškių įstatymų ar įstatų ir strategijų, įteisinančių mažų arba didelių kanalų veiklos ir priežiūros valdymą. Be stiprios VVA neįmanoma svajoti, kad bus pašalinti ūkininkų veiklos trūkumai, igyvendinta veiklos strategija, teisingai paskirstytas vanduo, patikimai jis tiekiamas ir laiku tiekiamas drëkinimo vanduo. 